\title{
BACTERIOPHAGE AMPLIFICATION ASSAY FOR DETECTION OF LISTERIA SPP. USING VIRUCIDAL LASER TREATMENT
}

\author{
Oliveira, I.C. ${ }^{1}$; Almeida, R.C.C. ${ }^{2 *}$; Hofer, E. ${ }^{3}$; Almeida, P.F. ${ }^{4}$ \\ ${ }^{1}$ Departamento de Ciências da Vida, Universidade Estadual da Bahia, Salvador, BA, Brasil; ${ }^{2}$ Departamento de Ciência dos \\ Alimentos da Escola de Nutrição, Universidade Federal da Bahia, Salvador, BA, Brasil; ${ }^{3}$ Departamento de Bacteriologia, Instituto \\ Oswaldo Cruz, Rio de Janeiro, RJ, Brasil; ${ }^{4}$ Departamento de Ciências da Biointeração, Instituto de Ciências da Saúde, \\ Universidade Federal da Bahia, Salvador, BA, Brasil.
}

Submitted: January 19, 2010; Approved: June 07, 2012.

\begin{abstract}
A protocol for the bacteriophage amplification technique was developed for quantitative detection of viable Listeria monocytogenes cells using the A511 listeriophage with plaque formation as the end-point assay. Laser and toluidine blue $\mathrm{O}$ (TBO) were employed as selective virucidal treatment for destruction of exogenous bacteriophage. Laser and TBO can bring a total reduction in titer phage (ca. $10^{8} \mathrm{pfu} / \mathrm{mL}$ ) without affecting the viability of L. monocytogenes cells. Artificially inoculated skimmed milk revealed mean populations of the bacteria as low as between $13 \mathrm{cfu} / \mathrm{mL}(1.11 \log \mathrm{cfu} / \mathrm{mL})$, after a $10-\mathrm{h}$ assay duration. Virucidal laser treatment demonstrated better protection of Listeria cells than the other agents previously tested. The protocol was faster and easier to perform than standard procedures. This protocol constitutes an alternative for rapid, sensitive and quantitative detection of L. monocytogenes.
\end{abstract}

Key words: Listeria, bacteriophage A511, laser light, detection, skimmed milk

\section{INTRODUCTION}

Listeria monocytogenes is a food-borne pathogen that can cause serious disease in humans. Since human listeriosis cases have previously been linked to consumption of contaminated foods, detection and control of this pathogen throughout the food production chain is of particular concern.

Conventional protocols for detection of pathogens in foods require a minimum of $48-72 \mathrm{~h}$ to obtain preliminary results (7). Numerous rapid methods have been developed for Listeria detection, but these methods often suffer from a lack of sensitivity or specificity or require expensive equipment or considerable technical expertise to perform (4).

The use of the lytic cycle of bacteriophage constitutes a powerful tool for the identification, typeability and detection of bacteria. Current applications of bacteriophage for this purpose includes recombinant bacteriophage containing reporter genes for the detection of Escherichia coli, Mycobacterium, Salmonella, and Listeria, which are indirectly revealed by expressing bioluminescence or ice nucleation. Recombinant bacteriophage applications, however, are costly to develop and require relatively sophisticated instrumentation for measuring 
either bioluminescence or ice nucleation. Simpler protocols have been developed employing the natural bacteriophage on bacteriophage lytic cycle that require only the bacteriophage and classic laboratory-based culture media and these are termed bacteriophage amplification assays $(14,19)$.

Listeria bacteriophage A511 is a virulent bacteriophage for this genus and is unrelated to all other Listeria bacteriophages. A511 has an extremely broad host range, being capable of lysing approximately $95 \%$ of all L. monocytogenes strains of serovars $1 / 2$ and $4 \mathrm{~b}$. This makes it useful in bacteriophage typing of listeriae and renders it a promising candidate for development of a specific reporter vehicle for rapid detection of Listeria spp. in foods and environmental samples (12).

Bacteriophage amplification is based on the principle that when a bacteriophage interacts with its host bacterium it injects its genetic material into the host. In this form the bacteriophage genes are protected by the bacterium from chemical and physical agents that would normally destroy the free bacteriophage. This is achieved without affecting the viability of the infected target bacteria. Upon destruction of all free phages, the only viable phage present in the assay will come from the previously infected host bacteria. If no host bacteria were available then there would be no subsequent release of viable phage (22). Subsequently, any resulting plaques are derived only from infected target organisms.

The effectiveness of the assay is determined by comparing the number of plaques produced on a lawn of helper bacteria with the number of colonies produced from equivalent samples. The specificity, sensitivity, discriminatory power and rapid replication of the bacteriophage makes the phage amplification technique an efficient way for a presumptive diagnostic $(17,21,23)$.

Graham (6) described the bacteriophage amplification assay for the diagnosis of tuberculosis. It could detect as few as 100 mycobacteria/mL from the patient's sputum samples in 10 hours and had the advantage that it could determine whether a particular mycobacteria strain was drug-resistant (3). Stewart et al. (22) presented a similar method for characterization of Pseudomonas aeruginosa and Salmonella serotype Typhimurium with detection limits of 40 and 600 bacteria/mL, respectively, in a period of 4 hours.

The bacteriophage amplification technique was also used by Park et al. (14) and according to the authors, infection time of 1 to 3 hours before addition of virucidal agent was sufficient for detecting 60 cells of Mycobacterium tuberculosis present in $1 \mathrm{~mL}$ of patient's sputum.

Favrin et al. (4) developed a novel immunomagnetic separation-bacteriophage assay for Salmonella Enteritidis. The method was capable of detecting less than $10^{4}$ colony forming units (cfu)/mL in 4 to 5 hours (IMS-bacteriophage). In another study, using the same method, Favrin et al. (5) detected Salmonella Enteritidis and Escherichia coli 0157:H7 artificially inoculated in skimmed milk powder, chicken rinses, and ground beef. In all foods tested, the IMS-bacteriophage assay was able to detect an average of $3 \mathrm{cfu}$ of $S$. Enteritidis in $25 \mathrm{~g}$ or $\mathrm{mL}$ of food sample.

This work describes a bacteriophage amplification assay for the rapid and quantitative detection of viable Listeria cells using laser light and toluidine blue $\mathrm{O}$ (TBO) as the selective virucidal treatment. These methods are based on the ability of bacteriophage to infect the target bacteria, express its lytic cycle and be revealed by their replication in helper sensitive bacteria.

\section{MATERIALS AND METHODS}

\section{Bacterial strains, bacteriophage, media and culture conditions}

The bacteria and phage used in this study were: Listeria monocytogenes Scott A, a 4b serotype (ATCC 15313), Listeria ivanovii WSLC 3009 (SLCC 4769), and bacteriophage A511 (provided by Dr. M. Loessner, Switzerland). L. ivanovii was used as helper cells for A511 phage (9). Listeria cultures strains were stored on Hogness medium (1.3 mM K $\mathrm{HPO}_{4}$. $3 \mathrm{H}_{2} \mathrm{O} ; 1.3 \mathrm{mM} \mathrm{KH}{ }_{2} \mathrm{PO}_{4} ; 2.0 \mathrm{mM}$ citrate-Na.2 $\mathrm{H}_{2} \mathrm{O} ; 1.0 \mathrm{mM}$ 
$\mathrm{MgSO}_{4} .7 \mathrm{H}_{2} \mathrm{O} ; 4.4 \%$ (v/v) glycerol) and frozen at $-80{ }^{\circ} \mathrm{C}$. Before use, cultures were activated in Brain Heart Infusion broth (Difco, Code No. 0037-17-8) supplemented with 0.5\% $(\mathrm{w} / \mathrm{v})$ yeast extract (Difco Code No. 0127-01-7) (BHI-YE) at $35{ }^{\circ} \mathrm{C}$ for $4 \mathrm{~h}$ in a shaker (Innova, model 4080, Brazil) at 150 rpm.

In all experiments, overlay, semi-soft agar was prepared by adding $0.5 \%(\mathrm{w} / \mathrm{v})$ agar to BHI-YE containing $0.01 \%(\mathrm{w} / \mathrm{v})$ $\mathrm{CaCl}_{2}$ (Sigma Aldrich - Poole, United Kingdom). To improve phage plaques $0.75 \%(w / v)$ glycine (Sigma Aldrich - Poole, United Kingdom) was added to the top layer agar (9). Appropriate bacterial dilutions were made in lambda buffer,6 $\mathrm{mmol} / \mathrm{l}$ Tris buffer, $\mathrm{pH} 7.2 ; 10 \mathrm{mmol} / 1 \mathrm{Mg}\left(\mathrm{SO}_{4}\right)_{2} .7 \mathrm{H}_{2} \mathrm{O} ; 50$ $\mu \mathrm{g} / \mathrm{mL}$ gelatin.

For the analysis of the virucidal treatment over Listeria cells, an overnight culture of L. monocytogenes was centrifuged at $12,000 \mathrm{x}$ g for $10 \mathrm{~min}$, washed once in lambda buffer and serially diluted. Viable cell numbers were determined by plating dilutions of cell suspensions onto BHIYE agar $(1.5 \% \mathrm{w} / \mathrm{v})$, in triplicate, and by incubating the plates at $30{ }^{\circ} \mathrm{C}$ for $48 \mathrm{~h}(21)$. To check for undesirable effects of the virucidal treatment on listeriae cells, was determined the counts by measuring colony-forming units $(\mathrm{cfu} / \mathrm{mL})$.

\section{Preparation and titration of A511 stock suspensions}

L. ivanovii was used for large-scale bacteriophage propagation, according to Loessner et al. (11). A511 stock suspensions were tittered after serial dilutions in lambda buffer, and addition $(10 \mu \mathrm{l})$ to molten overlay agar $\left(45^{\circ} \mathrm{C}\right)$ previously added with an overnight culture of L. ivanovii (100 $\mu 1$, ca. $\left.10^{8} \mathrm{cfu} / \mathrm{mL}\right)$. The plates were incubated at $30{ }^{\circ} \mathrm{C}$ for 24 $\mathrm{h}$ and the plaques counted $(\mathrm{pfu} / \mathrm{mL})$ in plates containing between 30 and 300 plaques (10). Phage stocks were stored at $18^{\circ} \mathrm{C}$ until use.

\section{Assay parameters}

Infection period: To determine the latency period and the number of bacteriophage particles after infection, $10 \mu \mathrm{l}$ of bacteriophage suspension $\left(10^{3} \mathrm{pfu} / \mathrm{mL}\right)$ were mixed with $10 \mu \mathrm{l}$ of L. monocytogenes cells $\left(10^{2} \mathrm{cfu} / \mathrm{mL}\right)$ and the number of particles after infection was monitored for $70 \mathrm{~min}$, observing the production of bacteriophage particles at intervals of ten minutes. This time course was also used to establish the best time (burst time) for infection (14).

Bacteria and phage preparations: Two different populations of L. monocytogenes, 10 and $10^{2} \mathrm{cfu} / \mathrm{mL}$, were used. Free bacteriophage cultures were used as controls in all assays. The cells was diluted with lambda buffer with $0.01 \%$ Tween 80 (Merck, Brazil), and $10 \mu$ of the sample was spread onto BHI-YE agar plates. The plates were incubated at $35{ }^{\circ} \mathrm{C}$ for 24-48 $\mathrm{h}$ and the colonies were counted on plates containing between 30 and 300 colonies. Tween 80, a common detergent, was added to prevent the aggregation of the cells of the Listeria. Bacteriophage concentration varied between $2.9 \times 10^{8}$ to $5.0 \times 10^{8} \mathrm{pfu} / \mathrm{mL}$. From each bacteriophage suspension $10 \mu \mathrm{l}$ were taken and added to $4 \mathrm{~mL}$ of top layer agar BHI $\left(45^{\circ} \mathrm{C}\right)$ containing $100 \mu \mathrm{l}$ of a recent active culture of L. ivanovii, mix gently and pour onto BHI-YE agar supplemented with $0.01 \%$ $\mathrm{CaCl}_{2}$. The plates were incubated at $30{ }^{\circ} \mathrm{C}$ for $8-12 \mathrm{~h}$ and the plaques counted in plates containing between 30 and 300 plaques.

\section{Bacteriophage amplification assay}

Detection of $\boldsymbol{L}$. monocytogenes in lambda buffer: A511 preparations (titer varied between $2.9 \times 10^{8}$ to $5.7 \times 10^{8}$ $\mathrm{pfu} / \mathrm{mL}$ ) were mixed with two different populations of $L$. monocytogenes (ca. 10 and $10^{2} \mathrm{cfu} / \mathrm{mL}$ ). This protocol was performed as follows: first $12.5 \mu \mathrm{l}$ of bacteria suspensions (ca. 10 and $10^{2} \mathrm{cfu} / \mathrm{mL}$ ) were mixed with $12.5 \mu \mathrm{l}$ of phage suspension and incubated at $25^{\circ} \mathrm{C} / 15$ min under shaking at 150 rpm, to allow infection. Such temperature was chosen to lower the listerial multiplication rate (10). Next, $25 \mu \mathrm{l}$ of toluidine blue O (TBO) (Sigma-Aldrich, C.I. 52040) $(200 \mu \mathrm{g} / \mathrm{mL})$ in combination with laser light (Laser Beam, model DR 500, Laser Solutions Tecnologia Ltda, Brazil) were mixed with the cells/phage solution. To improve the penetration of photoactive 
dye in the bacterial cells, the sample was agitated for $5 \mathrm{~min}$ at $25{ }^{\circ} \mathrm{C}$, followed by the application of non ablative laser (diode, wavelength $660 \mathrm{~nm}$, power $50 \mathrm{~mW}, 2 \mathrm{~mm}$ spot under continuous wave $-\mathrm{cw})$. A pilot test was carried out to establish optimized time and power conditions. Then, laser light was programmed with an exposure time of $15 \mathrm{~min}$ and an energy density of 30 $\mathrm{J} / \mathrm{cm}^{2}$. Four milliliters of overlay, semi-soft agar containing 100 $\mu 1$ of $L$. ivanovii were added to $10-\mu 1$ portions of the phage- $L$. monocytogenes mixture obtained from the treatment combinations listed. After incubation at $30{ }^{\circ} \mathrm{C}$ for $8-12 \mathrm{~h}$, the number of plaques $(\mathrm{pfu} / 10 \mu \mathrm{l})$ was determined $(10,21)$. Negative controls were prepared in duplicate by using lambda buffer plus Tween 80 instead of bacterial cells, in the presence of phage particles. Colony counts of the serially diluted target L. monocytogenes cells were prepared by substituting the bacteriophage with lambda buffer.

\section{Detection of $L$. monocytogenes inoculated in skimmed} milk: An aliquot of $900 \mu \mathrm{l}$ of commercially sterilized skim milk was inoculated with $100 \mu \mathrm{l}$ of the L. monocytogenes Scott A (ca. 10 and $10^{2} \mathrm{cfu} / \mathrm{mL}$ ). The samples with $L$. monocytogenes were left in a class II biosafety cabinet (Labconco II, model 221, Brazil) for $15 \mathrm{~min}$ at $21{ }^{\circ} \mathrm{C}$ to allow the attachment of bacteria to the milk before undergoing treatment (18). For detection of the bacteria in the milk samples, the experiment was performed, as mentioned before for lambda buffer, by adding bacteriophage (ca. $2.9 \times 10^{8}$ to $5.7 \times 10^{8} \mathrm{pfu} / \mathrm{mL}$ ) to the milk samples for the pre-established, optimized time and power conditions, treating with TBO, and then using the laser to destroy free phage. The use of laser light was programmed as follows:

Treatment 1: exposure time of 15 min and energy density of $30 \mathrm{~J} / \mathrm{cm}^{2}$.

Treatment 2: exposure time of $7 \mathrm{~min}$ and energy density of $14 \mathrm{~J} / \mathrm{cm}^{2}$.

Treatment 3: exposure time of 5 min and energy density of 7 $\mathrm{J} / \mathrm{cm}^{2}$.

Detection of $L$. monocytogenes in artificially contaminated

\section{skimmed milk by standard procedure}

For detection of the bacteria inoculated in sterile skimmed milk an aliquot of $900 \mu \mathrm{l}$ of the milk was inoculated with 100 $\mu \mathrm{l}$ of L. monocytogenes Scott A (ca. 10 and $10^{2} \mathrm{cfu} / \mathrm{mL}$ ). The samples with L. monocytogenes were left in a class II biosafety cabinet for $15 \mathrm{~min}$ at $21^{\circ} \mathrm{C}$ to allow the attachment of bacteria to the milk (18). Test samples $(100 \mu l)$ were spread on Modified Oxford Listeria Selective Agar (MOX, Difco Code No. 222530) and counts of bacterial was determined by measuring colony-forming units (cfu) (2).

\section{Statistical analysis}

To investigate the effectiveness of laser light in the detection of L. monocytogenes Scott A, a 4b serotype (ATCC 15313), three replicate experiments were conducted, with ten samples evaluated per replicate. All counts of bacteria $(\mathrm{cfu} / \mathrm{mL})$ recovered from skimmed milk were transformed to logarithms before computing means and standard deviations.. Data were subjected to the Statistical Analysis System for analysis of variance and Duncan's multiple range test (SPSS 2.3 for Windows pocket program) to determine if significant differences $(P<0.05)$ in populations of $L$. monocytogenes recovered existed among mean log values.

\section{RESULTS}

The results obtained in propagation of bacteriophage A511 amplification showed that incubation of $50 \mathrm{~min}$ resulted in an increase in the amplification signal. The highest peak of bacteriophage particles production (burst size) was reached in $60 \mathrm{~min}$ (136 pfu). Phage particles (i.e., lyses) were first observed at $40 \mathrm{~min}$. The adsorption and wash steps did not exceed this time. Results showed that the incubation time of 60 min for amplification was enough to complete an infection cycle and that the bacterial population during the detection (reveal) step was higher than during the infection step. This fact is mentioned by Loessner and Scherer (1995) and indicates that the opportunities for the new phage progeny to find and infect the target cell are large. 
The effects of laser and TBO on L. monocytogenes and bacteriophage A511 viability are presented on Table 1. Preliminary results using lambda buffer suggested that a 30 $\mathrm{J} / \mathrm{cm}^{2}$ for $15 \mathrm{~min}$ would be the best conditions. However, with inoculated skimmed milk samples, this laser intensity was lethal to L. monocytogenes. The best performance of virucidal agent in skimmed milk samples was demonstrated to be 14
$\mathrm{J} / \mathrm{cm}^{2}$ for $7 \mathrm{~min}$. The use of bacteriophage A511, coupled with laser light and TBO to eliminate extracellular phage particles, could detect numbers of L. monocytogenes as low as $13 \mathrm{cfu} / \mathrm{mL}$ (1.11 log cfu/mL).

The statistic analysis showed no significant difference $(P>0.05)$ between detections methods used, standard procedure and bacteriophage amplification (Table 2).

Table 1. Detection of Listeria monocytogenes Scott A by the bacteriophage amplification assay using toluidine blue O (TBO) and non ablative laser* as virucidal agent.

\begin{tabular}{|c|c|c|}
\hline \multirow[t]{2}{*}{ Treatments } & \multicolumn{2}{|c|}{ Mean counts } \\
\hline & Over $10 \mathrm{cfu} / \mathrm{mL}$ & Over $100 \mathrm{cfu} / \mathrm{mL}$ \\
\hline Lambda buffer & & \\
\hline $\mathrm{C}_{1}=$ Laser $30 \mathrm{~J} / \mathrm{cm}^{2}$ for $15 \mathrm{~min}+$ cell & $3.0 \pm 2.12$ & $75.0 \pm 35.35$ \\
\hline $\mathrm{C}_{2}=$ Laser $30 \mathrm{~J} / \mathrm{cm}^{2}$ for $15 \mathrm{~min}+$ phage & 0 & 0 \\
\hline Skimmed milk & & \\
\hline $\mathrm{C}_{1}=$ Laser $30 \mathrm{~J} / \mathrm{cm}^{2}$ for $15 \mathrm{~min}+$ cell & Injurious & Injurious \\
\hline $\mathrm{C} 2=$ Laser $30 \mathrm{~J} / \mathrm{cm}^{2}$ for $15 \mathrm{~min}+$ phage & 0 & 0 \\
\hline Skimmed milk & & \\
\hline $\mathrm{C}_{1}=$ Laser $14 \mathrm{~J} / \mathrm{cm}^{2}$ for $7 \mathrm{~min}+$ cell & $13.0 \pm 2.55$ & $104.0 \pm 2.79$ \\
\hline $\mathrm{C}_{2}=$ Laser $14 \mathrm{~J} / \mathrm{cm}^{2}$ for $7 \mathrm{~min}+$ phage & 0 & 0 \\
\hline Skimmed milk & & \\
\hline $\mathrm{C}_{1}=$ Laser $7 \mathrm{~J} / \mathrm{cm}^{2}$ for $5 \mathrm{~min}+$ cell & $12.0 \pm 0.46$ & $101.0 \pm 6.02$ \\
\hline $\mathrm{C}_{2}=$ Laser $7 \mathrm{~J} / \mathrm{cm}^{2}$ for $5 \mathrm{~min}+$ phage & $7.0 \pm 5.31$ & $7.0 \pm 5.44$ \\
\hline
\end{tabular}

$\mathrm{C}_{1}=$ cells control; $\mathrm{C}_{2}=$ phage control

Phage title $=2.9$ to $5.7 \times 10^{8} \mathrm{pfu} / \mathrm{mL}$

$* \lambda 660 \eta \mathrm{m}, 50 \mathrm{~mW}, 2 \mathrm{~mm}$ spot under continuous wave $-\mathrm{cw}$

Table 2. Detection of Listeria monocytogenes Scott A in skimmed milk by the bacteriophage amplification assay and standard method

\begin{tabular}{|c|c|c|c|}
\hline \multicolumn{2}{|c|}{$\begin{array}{l}\text { Standard method } \\
(\log \mathrm{cfu} / \mathrm{mL})\end{array}$} & \multicolumn{2}{|c|}{$\begin{array}{l}\text { Phage amplification using laser light* } \\
(\log \mathrm{cfu} / \mathrm{mL})\end{array}$} \\
\hline $\begin{array}{c}\text { Approx. } 1 \log \mathrm{cfu} / \mathrm{mL} \\
1.18 \pm 1.01^{\mathrm{a}}\end{array}$ & $\begin{array}{l}\text { Approx. } 2 \log \mathrm{cfu} / \mathrm{mL} \\
2.05 \pm 0.43^{\mathrm{b}}\end{array}$ & $\begin{array}{c}\text { Approx. } 1 \log \mathrm{cfu} / \mathrm{mL} \\
1.11 \pm 1.23^{\mathrm{a}}\end{array}$ & $\begin{array}{l}\text { Approx. } 2 \log \mathrm{cfu} / \mathrm{mL} \\
2.02 \pm 0.32^{\mathrm{b}}\end{array}$ \\
\hline
\end{tabular}

\section{DISCUSSION}

Infection and the lyses kinetics are important considerations in phage amplification assays. The latency period (burst time) of the lytic cycle of phage A511 was investigated to optimize assay variables. The increase in phage particles after 50 min was noted and the highest level was achieved at $60 \mathrm{~min}$ (burst time). The time between 30 and 40 min represents the latency period of the listeriophage A511.

According to Park et al. (14) sufficient time of infection prior to virucide addition is required to achieve good results, but the time of infection should not be too long, so that the released progeny of bacteriophages is destroyed. Furthermore, assay signal amplification relating to lytic burst could 
conceivably be obtained following virucide treatment and virucide inactivation by allowing additional incubation prior to plating.

A critical component of the bacteriophage amplification assay was the provision of a potent virucidal agent that selectively maintained the L. monocytogenes cells alive. As part of a search for such agents we had examined a wide range of physical, chemical and enzymatic treatments against Listeria bacteriophage A511 and the host L. monocytogenes cells (unpublished results). Selective virucidal activity was observed for the tannic acid and heat treatment at $65{ }^{\circ} \mathrm{C}$. Also, the filtration treatment has been demonstrated to be an alternative method just in case we could not find a more practical chemical or physical treatment to destroy the virus. When this method was adapted to a phage amplification assay it was possible to detect Listeria monocytogenes, however it is more expensive, laborious and difficult to reproduce. The best heat treatment found to kill the virus was $65{ }^{\circ} \mathrm{C}$ for $70 \mathrm{sec}$, reducing the plaque counts by approximately $7 \log$ cycle. Heat treatment at $65{ }^{\circ} \mathrm{C}$ for more than $30 \mathrm{sec}$ severely damaged the cell population of L. monocytogenes as revealed by the pinpoint colonies formed. Although the reduction in the number of colonies of L. monocytogenes was not very high, the time required for cell counts was longer and the small colony size suggests a strong influence on the cell metabolic activities. The same phenomenon was observed with proteinase treatment (proteinase k). In contrast, phage and Listeria cells showed a wide tolerance to the chlorine concentrations used. Some reduction in the cell population of Listeria was observed on chlorine concentrations above $10 \mathrm{mg} / \mathrm{l}$.

Although Stewart et al. (20) found that acetic acid has good selective virucidal activity for Listeria phage ATCC 23074-B1, we did not find the same results for the Listeria phage A511 using this acid at concentrations of 0.3 to $0.6 \%$. Our work shows no virucidal activity against the A511 particles while the Listeria cells were slightly affected by this acid at the greatest concentration used. Extracts of Cardamom and Pomegranate have been used alone or in combination with ferrous sulfate as selective virucidal agents (22). The use of pomegranate rind extract at $1.3 \%$ in combination with ferrous sulfate $4.8 \mathrm{mmol} / 1$ has a profound selective virucidal activity against bacteriophages of Pseudomonas, Staphylococcus and Salmonella without affecting the bacterial cell hosts (22). Using the same combined treatment, varying the pomegranate rind extract from 0.0001 to $1.0 \%$ against Listeria phage A511 we get no reduction on phage or L. monocytogenes counts. However, when we used tannic acid, one of the active components of pomegranate rind extract, we got the best selective virucidal action. Tannic acid showed an unexpected virucidal activity when sterilized by heat when compared to filtration. It seems that heat increases expose the microbicidal properties of the tannic acid. Selective virucidal action was observed at concentrations of $13 \mathrm{mg} / \mathrm{l}$ or lower, where it was able to reduce the number of phage particles (up to a $6 \log$ difference) without affecting L. monocytogenes cells. Above this concentration the Listeria cell counts were affected. Using a combination of tannic acid at $13 \mathrm{mg} / \mathrm{l}$ and heat treatment 65 ${ }^{\circ} \mathrm{C}$ per $30 \mathrm{sec}$ we got a 9 log cycle reduction of Listeria phage A511, but only a $1.6 \mathrm{log}$ cycle reduction for Listeria counts. Unfortunately the combined treatment did not have good reproducibility probably because of the difficulty in assuring temperature equilibrium for the phages and cells in such a short time. We tried to use tannic acid and heat treatment $\left(65^{\circ} \mathrm{C}\right.$ for $30 \mathrm{sec}$ ) and immediately putting the Eppendorf tubes on ice but we did not get better results.

Given our objective to select agents with maximal virucidal activity against Listeria phage A511whilst having no effect on L. monocytogenes, tannic acid filter sterilized alone or in combination with ferrous sulfate appears singularly successful. However, there was also an accentuated listericidal activity when tannic acid was used at concentrations higher than $13 \mathrm{mg} / \mathrm{l}$.

Ferrous sulfate has a pronounced virucidal activity against Staphylococcus and Salmonella phages but no action on Pseudomonas NCIMB 10884 and 10116 phages (14). For L. monocytogenes and phage combination tested by us there is a 
simple treatment that can eliminate A511 phage activity without affecting bacterial viability. It seems that the tannic acid promotes virucidal activity while the ferrous sulfate appears to provide significant protection to the $L$. monocytogenes cells. Our results showed that tannic acid (10 to $20 \mathrm{mg} / \mathrm{l})$ plus $\mathrm{FeSO}_{4}(4.8 \mathrm{mmol} / \mathrm{l})$ had a good virucidal activity, but the colonies of L. monocytogenes were pinpointed (stressed).

The mechanism of activity of the virucide ferrous ammonium sulfate (FAS) has not been elucidated. According to Park et al. (14), unpublished preliminary data suggesting that oxidative damage does not constitute the mode of action have been reported previously. The authors also discovered that the chelating agent trisodium citrate supplemented with calcium chloride is a specific, efficient, and cost-effective alternative agent that protects the phage D29 from FAS.

Similar studies were carried out with Mycobacterium tuberculosis, the phage amplified biological assay (the PhaB assay) by Eltringham et al. (3). The protocol was first described as a rapid (2 to 4 days) and sensitive phenotypic method for testing the drug susceptibility of M. tuberculosis isolates. According to the authors, heat treatment or processing with $\mathrm{NaOH}$ or Sodium Duodecyl Sulfate (SDS) was shown to inactivate or wash away the inhibitory activity, suggesting that the phage activity is of a proteinaceous nature. However, the heat treatment required was beyond the temperature permissive for $M$. tuberculosis survival, nullifying its value as a sample processing method.

According to Lambrechts et al. (8), photodynamic therapy (PDT) is a process in which the activation of photo reactive compounds (photoactive) by light energy can react with molecules from its immediate environment by electron or hydrogen transfer, leading to the production of radicals (type 1 reaction) or alternatively, photoactive compounds can transfer their energy to oxygen, generating highly reactive singlet oxygen (type 2 reaction). Both pathways can lead to cell death (8). Due to the highly reactive nature of the radicals formed through this process, activity is confined to their immediate environment. Thus, activity is selective and dependent on the delivery of the photoactive compound to the target $(13,16)$.

The lethal laser photo-sensitization is a modality of treatment based in a cytotoxic photochemical reaction in which an intense source of light, produced by a laser system, activates a photo-sensitizer, absorbed by the cells, and this activation induces a series of metabolic reactions that culminate in a cell death. Non ablative laser is characterized by inducing photobiological process without destructive action and the treatment have the function of repair the cell biological balance getting better the conditions of tissue vitality (15).

The photodynamic bactericidal effect of the photoactive dyes acriflavine neutral, rose bengal, phloxine $\mathrm{B}$, and malachite green (oxalate salt) at concentrations of 5 to $5,000 \mu \mathrm{g} / \mathrm{mL}$ against Listeria monocytogenes LJH 375), was investigated (1). Incubation of the bacteria with acriflavine neutral under illumination resulted in a significant reduction in cell numbers compared with dark incubation. Rose bengal caused a significant killing effect for bacteria incubated both in the dark and under illumination, and malachite green was active under illumination. According to the authors, the extent of bacterial killing depended on the nature and concentration of the dye conjugate and the type of microorganism.

In the present study, a pilot test was carried out with lambda buffer to establish the optimum combination of laser energy density (non ablative laser) and exposure time for which bacteriophage particles could be destroyed without affecting the viability of $L$. monocytogenes cells. However, this pre-determined condition was inappropriate for Listeria monocytogenes inoculated in skimmed milk.

It is important to mention that listeriophage-based assays using A511 phage will be able to detect the whole genus (i.e. Listeria spp.), not only to L. monocytogenes, the species of most interest for food safety worldwide.

Researchers have experienced difficulties in using selective virucidal treatment for destruction of exogenous bacteriophage $(4,5,14,22)$. The laser light used in this study demonstrated better protection to Listeria cells than the other 
agents previously investigated by us. Considering the results obtained with lambda buffer and skimmed milk in the present work, it could be concluded that further investigation can be conducted with other foods either naturally or artificially contaminated with L. monocytogenes to establish a good set of conditions for laser light as virucidal treatment.

\section{ACKNOWLEDGEMENTS}

We would like to thank to "Biotecnologia e Ecologia de Microrganismos" laboratory staff who collaborated with us in this study. We would like to acknowledge Dr. Roberto Gonçalves Junqueira helping in the statistical analyses, and Dr. David Moraga for his suggestions on the technical contents of this work. Dr. Martin Loessner generously provided us with the bacteriophage A511 and Listeria ivanovii.

\section{REFERENCES}

1. Brovko, L.Y.; Meyer, A.; Tiwana, A.S.; Chen, W.; Liu, H.; Filipe, C.D.M.; Griffiths, M.W. (2009). Photodynamic Treatment: A Novel Method for Sanitation of Food Handling and Food Processing Surfaces. J. Food Prot. 72, 1020-1024.

2. Donnelly, C.W.; Brackett, R.E.; Doores, S.; Lee, W.H.; Lovett, J. (1992). Listeria. In: Vanderzant, C.; Splitstoesser, D.F. (Eds.), Compendium of Methods for Microbiological Examination of Foods, 3rd ed. American Public Health Association, Washington, pp. 637-663.

3. Eltringham, I.J.; Drobniewsski, F.A.; Mangan, J.A.; Butcher, P.D.; Wilson, S.M. (1999). Evaluation of reverse transcription-per and a bacteriophage-based assay for rapid phenotypic detection of rifampicina resistance in clinical isolates of Mycobacterium tuberculosis. J. Clin. Microbiol. 37: 3524-3527.

4. Favrin, S.J.; Jassim, S.A.; Griffiths, M.W. (2001). Development and optimization of a novel immunomagnetic separation-bacteriophage assay for detection of Salmonella enterica serovar Enteritidis in broth. Appl. Environ. Microbiol. 67: 217-224.

5. Favrin, S.J.; Jassim, S.A.; Griffiths, M.W. (2003). Application of a novel immunomagnetic separation-bacteriophage assay for the detection of Salmonella enteritidis and Escherichia coli $\mathrm{O} 157: \mathrm{H} 7$ in food. Int. J. Food Microbiol. 85: 63-71.

6. Graham, J. (1996). Timely test spots TB "in hours". New Scientist 151: 21.
7. Hagens, S.; Loessner, M.J. (2007). Mini-Review. Application of bacteriophages for detection and control of foodborne pathogens. Appl. Microbiol. Biotechnol. 76: 513-519.

8. Lambrechts, S.A.G.; Aalders, M.C.G.; Verbraak, F.D.; Lagerberg, J.W.M.; Dankert, J.B.; Schuitmaker, J.J. (2005). Effect of albumin on the photodynamic inactivation of microorganisms by a cationic porphyrin. $J$. Photochem. Photobio. B: Biol. 79: 51-57.

9. Lillehaug, D. (1997). An improved plaque assay for poor plaqueproducing temperate lactococcal bacteriophages. J. Appl. Microbiol.83: $85-90$.

10. Loessner, M.J., Busse, M. (1990). Bacteriophage typing of Listeria species. App. Environm. Microbiol. 56: 1912-1918.

11. Loessner, M.J.; Goeppl, S.; Busse, M. (1991). Comparactive inducibility of bacteriophage in naturally lysogenic and lysogenized strains of Listeria spp. by u.v. light and Mitomycin C. Lett. Appl. Microbiol. 12: 196-199.

12. Loessner, M.J.; Scherer, S. (1995). Organization and transcriptional analysis of the Listeria phage A511 late gene region comprising the major capsid and tail sheath protein genes cps and tsh. J. Bacteriol. 177: 6601-6609.

13. Millson, C.E.; Wilson, M.; MacRobert, A.J.; Bown, S.G. (1996). Exvivo treatment of gastric Helicobacter infection by photodynamic therapy. J. Photochem. Photobiol. B: Biol. 32: 59-65.

14. Park, D.J.; Drobniewsski, F.A.; Meyer, A.; Wilson, S.M. (2003). Use of a phage-based assay for phenotypic detection of mycobacteria directly from sputum. J. Clin. Microbiol. 41: 680-688.

15. Reinisch, L. (1996). Laser physics and tissue interactions. Otolaryngol. Clin. North Am. New York 29: 893-914.

16. Rovaldi, C.R.; Pievsky, A.; Sole, N.A.; Friden, P.M.; Rothstein, D.M.; Spacciapoli, P. (2000). Photoactive porphyrin derivative with broadspectrum activity against oral pathogens in vitro. Antim. Agents and Chemoth. 44: 3364-3367.

17. Sharma, N.C.; Bhatia, R.; Singh, S.; John, P.C.; Kumar, S.; Singh, H. (1994). Bacteriophage-typing in Salmonella bareilly. Epidemiol. Infection 112: 45-49.

18. Singh, N.; Singh, R.K.; Bhunia, A.K.; Stroshine, R.L. (2002). Effect of inoculation and washing methods on the efficacy of different sanitizers against Escherichia coli O157:H7 on lettuce. Food Microbiology 19: 183-193.

19. Siqueira, R.S.; Dodd, C.E.R.; Rees, C.E.D. (2003). Phage amplification assay as rapid method for Salmonella detection. Brazilian Journal of Microbiology 34: 118-120.

20. Stewart, G.S.A.B.; Jassim, S.A.A.;Denyer, S.P.; Rees, C.E.D.; Park, S.; Rostas-Mulligan, K. (1992). Methods for rapid microbial detection. PCT patent WO 92/02633.

21. Stewart, G.S.A.B.; Loessner, M.J.; Scherer, S. (1996). The bacteria lux gene bioluminescent biosensor revisited. ASM News 62: 297-301. 
22. Stewart, G.S.A.B.; Jassmin, A.A.; Denyers, P.; Newby, P.; Linley, K.; Dhir, V.K. (1998). The specific and sensitive detection of bacterial pathogens within $4 \mathrm{~h}$ using bacteriophage amplification. J. Appl. Microbiol. 84: 777-783.
23. Turpin, P.E.; Maycroft, K.A.; Bedford, J.; Rowlands, C.L.; Wellington, E.M.H. (1993). A rapid luminescent-phage based MPN method for the enumeration of Salmonella typhimurium in environmental samples. Lett. Appl. Microbiol.16: 24-27. 